\title{
Screening of six medicinal plant species for antileishmanial activity
}

FABIANA BORGES PADILHA FERREIRA ${ }^{1}$ MÁRCIA REGINA PEREIRA CABRAL ${ }^{2}$ MARIA HELENA SARRAGIOTTO ${ }^{3}$ CARLA MARIA MARIANO FERNANDEZ ${ }^{4}$ ZILDA CRISTIANI GAZIM ${ }^{4}$ RANULFO PIAU JUNIOR ${ }^{5}$

IZABEL GALHARDO DEMARCHI THAÍS GOMES VERZIGNASSI SILVEIRA ${ }^{1,7}$ MARIA VALDRINEZ CAMPANA LONARDONI ${ }^{1,7}$

${ }^{1}$ Posgraduate Program in Health Sciences Maringá State University, Maringá - Paraná State, Brazil

${ }^{2}$ Posgraduate Program in Pharmaceutical Sciences, Maringá State University, MaringáParaná State, Brazil

${ }^{3}$ Postgraduate Program in Chemistry, Maringá State University, Maringá - Paraná, Brazil

${ }^{4}$ Posgraduate Program in Biotechnology Applied to Agriculture, Universidade Paranaense UNIPAR, Umuarama - Paraná State, Brazil

${ }^{5}$ Posgraduate Program in Animal Science of the University of Paranaense, Universidade Paranaense UNIPAR, Umuarama - Paraná State, Brazil

${ }^{6}$ Federal University of Santa Catarina, Florianópolis - Santa Catarina State, Brazil

${ }^{7}$ Department of Clinical Analysis and Biomedicine, Maringá State University Maringá-Paraná State, Brazil

Accepted July 23, 2020

Published September 3, 2020
This study is aimed to investigate the in vitro antileishmanial activity of ethanolic, aqueous or dichloromethane extracts of leaves, flowers, fruits or roots, of six medicinal plant species, namely, Nectandra megapotamica, Brunfelsia uniflora, Myrcianthes pungens, Anona muricata, Hymenaea stigonocarpa and Piper corcovandesis. After isolation and analysis of chemical components by ultra-high performance liquid chromatography-high-resolution tandem mass spectrometry (UHPLC-HRMS/MS), the extracts were also tested for toxicity in J774.A1 macrophages and human erythrocytes. Phenolic acids, flavonoids, acetogenins, alkaloids and lignans were identified in these extracts. Grow inhibition of promastigotes forms of Leishmania amazonensis and Leishmania braziliensis and the cytotoxicity in J774.A1 macrophages were estimated by the XTT method. The most promising results for $L$. amazonensis and L. braziliensis were shown by the ethanolic extract of the fruits of Hymenaea stigonocarpa and dichloromethane extract of the roots of Piper corcovadensis, with $I C_{50}$ of 160 and $150 \mu \mathrm{g} \mathrm{mL}{ }^{-1}$, resp. Ethanolic extracts of $A$. muricata (leaf), B. uniflora (flower and leaf), M. pungens (fruit and leaf), N. megapotamica (leaf), and aqueous extract of $H$. stigonocarpa (fruit) showed $I C_{50}>170 \mu \mathrm{g} \mathrm{mL}^{-1}$ for L. amazonensis and $>200$ $\mu \mathrm{g} \mathrm{mL} \mathrm{m}^{-1}$ for L. braziliensis. The extracts exhibited low cytotoxicity towards J774.A1 macrophages with $\mathrm{CC}_{50}$ $>1000 \mu \mathrm{g} \mathrm{mL} \mathrm{m}^{-1}$ and hemolytic activity from 0 to $46.1 \%$.

Keywords: Piper corcovadensis, Hymenaea stigonocarpa, antileishmanial, Leishmania amazonensis, Leishmania braziliensis, cytotoxicity, hemolysis

Leishmaniasis is an infectious disease caused by protozoa of the genus Leishmania. The clinical manifestations depend on the species of Leishmania and the host immune response. Cutaneous leishmaniasis (CL) is the most common form of leishmaniasis and

\footnotetext{
*Correspondence; e-mail: fabianabpferreira@gmail.com; fbpferreira@hotmail.com
} 
causes skin lesions, mainly ulcers on exposed body parts, leaving life-long scars and serious disability or stigma. Leishmania braziliensis is associated with the cutaneous and mucocutaneous form (MCL), whereas Leishmania amazonensis is related to the diffuse cutaneous forms (DCL) (1). MCL and DCL are the most severe forms due to the destructive disfiguring lesions, which can result in increased individual and social stigma as well as suicidal ideas (2). Approximately $95 \%$ of cutaneous leishmaniasis occur in the American continent, Mediterranean bay, Middle-East and Central Asia. The World Health Organization has estimated that about 600 thousand to 1 million new cases occur worldwide a year, and more than $90 \%$ of the cases of MCL occur in Bolivia, Brazil, Peru and Ethiopia (3).

For decades, the first choice to treat this disease has been the utilization of pentavalent antimony, and the second choice has utilized treatment drugs such as amphotericin $\mathrm{B}$ and pentamidine. However, these drugs present high toxicity, resistance and parenteral administration, high cost and relatively long treatment regimen (4). Other drugs have also been used as an alternative tool in cases of therapeutic failure, abandon and parasitic resistance, such as imidazole, miltefosine, paromomycin and liposomal amphotericin B. Nevertheless, not all the drugs are available or accessible to the most affected populations, making necessary to search for new sources of bioactive molecules essential to discover new medicines and alternative therapies (5).

Over the years, humans have been using nature to treat a broad spectrum of diseases, mainly infectious and parasitic ones (6). The need for new, safer and more effective treatments of leishmaniasis stimulated research with natural products obtained from plants with antileishmanial activity. A lot of studies have shown the potential of medicinal plants to treat several diseases, working as a base for the formulation of phytotherapeutic drugs or as a source to obtain active principles (7).

In this context, this study is aimed to chemically characterize nine extracts belonging to six different medicinal plants belonging to different families, to investigate their effects on the promastigote forms of L. amazonensis and L. braziliensis, and also, evaluate their cytotoxicity to J774.A1 macrophages and erythrocytes.

\section{EXPERIMENTAL}

\section{Plant material}

The exsiccata data and the location of the collection are presented in Table I for five native species of Brazil: Brunfelsia uniflora (Pohl.) David Don, Hymenaea stigonocarpa Martius ex. Hayne, Myrcianthes pungens (Otto Berg) Diego Legrand, Nectandra megapotamica (Spreng) Mez and Piper corcovadensis (Miq.) C. DC, and one introduced and well-acclimated species in Brazil, Annona muricata Linnaeus.

Crude extracts. - The crude extracts of N. megapotamica leaves, B. uniflora leaves and flowers, $M$. pungens fruits and leaves and $H$. stigonocarpa fruits were obtained by dynamic maceration utilizing $96 \%(V / V)$ ethanol as solvent. For the fruits of $H$. stigonocarpa, an aqueous extract was prepared. The crude extract of $A$. muricata leaves was obtained in $95 \%$ $(V / V)$ ethanol. For the $P$. corcovandesis, roots were extracted in dichloromethane using a Soxhlet apparatus. All extracts were concentrated in a rotary evaporator (Tecnal ${ }^{\circledR}$, TE-211, Brazil) at $40{ }^{\circ} \mathrm{C}$ to obtain the crude extracts. 
Ultra-high performance liquid chromatography - high-resolution tandem mass spectrometry (UHPLC-HRMS/MS)

The extracts were analyzed by UHPLC (Nexera X2, Shimadzu, Japan) coupled with HRMS (QTOF Impact II, Bruker Daltonics Corporation, USA) equipped with an electro -spray ionization source. The capillary voltage was operated in negative and positive ionization mode, set at $4500 \mathrm{~V}$, and with an endplate offset potential of $-500 \mathrm{~V}$. The dry gas parameters were set at $8 \mathrm{~L} \mathrm{~min}^{-1}$ at $200{ }^{\circ} \mathrm{C}$ with a nebulization gas pressure of $4 \times 10^{5} \mathrm{~Pa}$. Data were collected from $\mathrm{m} / \mathrm{z} 50$ to 1300 with an acquisition rate of 5 spectra per second, and the ions of interest were selected by auto MS/MS scan fragmentation. Chromatographic separation was performed using a C18 column $(75 \times 2.0 \mathrm{~mm}$ i.d., $1.6 \mu \mathrm{m}$, Shim-Pack XR-ODS III, Shimadzu). The gradient mixture of solvents $\mathrm{A}\left(\mathrm{H}_{2} \mathrm{O}\right)$ and $\mathrm{B}$ (acetonitrile) was as follows: $5 \%$ B 0-1 min, $30 \%$ B 1-2 min, $95 \%$ B 2-8 min, maintained at $95 \%$ B 8-12 min, at $40{ }^{\circ} \mathrm{C}$. The identification of the compounds was proposed from a review of secondary metabolites found in species belonging of the genus Brunfelsia, Hymenaea, Myrcianthes, Nectandra, Piper and Annona. In addition, the mass error value was considered (the difference between the calculated exact mass and the experimental exact mass) (8). The mass error was calculated using the following equation:

$$
\text { Mass error }=\frac{(\text { exact }- \text { ion precursor })}{\text { ion precursor }} \times 10^{6} \text { in ppm }(\text { parts per million })
$$

\section{Cultivation and maintenance of promastigote forms}

Promastigote forms of L. amazonensis (MHOM/BR/1977/LTB0016) were provided by the Leishmania Collection from Oswaldo Cruz Institute (CLIOC, Rio de Janeiro, Brazil) and L. braziliensis (MHOM/BR/1987/M11272) were isolated from the patient carriers of American cutaneous leishmaniasis, attending the Laboratório de Ensino e Pesquisa em Análises Clínicas of the Maringá State University, Brazil, identified in the Instituto Evandro Chagas, Brazil (9). Promastigote forms were cultivated and kept at $25^{\circ} \mathrm{C}$ through weekly transplants in cultivation medium 199 (Sigma-Aldrich, USA) supplemented with $10 \%(V / V)$ fetal bovine serum (FBS, Cultilab, Brazil), $2 \mathrm{mmol} \mathrm{L}^{-1}$ L-glutamine and antibiotics (100 IU $\mathrm{mL}^{-1}$ penicillin and $0.1 \mu \mathrm{g} \mathrm{mL} \mathrm{m}^{-1}$ streptomycin (Sigma-Aldrich).

\section{Antileishmanial activity}

To evaluate the growth inhibition of promastigote forms of Leishmania, the parasites were cultivated until they reached the stationary phase. A suspension was prepared in RPMI 1640 medium to contain $4 \times 10^{7} \mathrm{~mL}^{-1}$ of parasites.

The parasite's viability was determined using the colorimetric method based on the reduction of the tetrazolium salt (XTT, 2,3-bis-(2-methoxy-4-nitro-5-sulfophenyl)-2H-tetrazolium-5-carboxanilide) (Sigma-Aldrich) to formazan, a colored, water-soluble compound (10). Briefly, the extracts were dissolved in Tween 80 and serially diluted with RPMI 1640 (Sigma-Aldrich, USA) from 1000 to $1.5 \mu \mathrm{g} \mathrm{mL}^{-1}$ in 96-well culture plates (TPP, Switzerland). Amphotericin B (AmB, Laboratório Cristalia, Brazil) was diluted in RPMI 1640 from 125 to $0.24 \mu \mathrm{g} \mathrm{mL} \mathrm{m}^{-1}$. A suspension in RPMI medium of L. amazonensis promastigote forms $(100 \mu \mathrm{L})$ from a logarithmic growth phase $\left(4 \times 10^{6}\right.$ parasites per $\left.100 \mu \mathrm{L}\right)$ was added to each well. 
After $24-\mathrm{h}$ incubation at $25^{\circ} \mathrm{C}, 100 \mu \mathrm{L}$ of a solution containing XTT $\left(0.2 \mathrm{mg} \mathrm{mL}^{-1}\right)$ and phenazine methosulfate (PMS, Sigma, USA) $\left(0.2 \mathrm{mmol} \mathrm{L}^{-1}\right)$ were added to each well.

The plates were incubated for $3 \mathrm{~h}$ at $37^{\circ} \mathrm{C}$. The results were measured in a microplate reader (ASYS Expert Plus, ASYS Hitech GmbH, Austria) at 450/620 nm. Amphotericin B was utilized as a reference drug and positive control of the treatment (parasite death). The $I C_{50}$ (minimum concentration for $50 \%$ inhibition) was calculated from a polynomial regression of the data comparing it to the negative control (non-treated parasites). The tests were performed in duplicate and replicated at least three times.

\section{Cytotoxicity against J774. A1 macrophages}

J774.A1 macrophages were cultivated in RPMI 1640 medium and distributed in 96well plates at the concentration of $1 \times 10^{6}$ cells $\mathrm{mL}^{-1}$ at $37^{\circ} \mathrm{C}$ in an atmosphere containing 5 $\%$ of $\mathrm{CO}_{2}$. Then, the cultivation medium was removed and the cells were washed several times with RPMI 1640 to remove non-adherent cells. The extract (1000 to $\left.1.5 \mu \mathrm{g} \mathrm{mL}{ }^{-1}\right)$ was added to each well. After $24 \mathrm{~h}$ of cultivation, $100 \mu \mathrm{L}$ of XTT was added to each well. The plates were incubated for $3 \mathrm{~h}$, and the absorbance was measured by a microplate reader at $450 / 620 \mathrm{~nm}$. The cytotoxic concentration sufficient to inhibit macrophages by $50 \%\left(C C_{50}\right)$ was calculated by the polynomial regression of data compared to the control of non-treated cells. The selectivity index (SI) was determined using the following equation:

$$
\mathrm{SI}=\mathrm{CC}_{50} \text { in cells } / \mathrm{IC}_{50} \text { in Leishmania }
$$

The tests were performed in duplicate and replicated at least three times.

\section{Hemolytic activity}

The toxicity to red blood cells was determined according to the method described by Valdez et al. (11) with modifications. Human blood samples were obtained by venipuncture from six healthy women donors, aged 21-60 years old, non-smokers, who were not on any medication, and suffered from no chronic diseases. The donors completed "Consent form" agreeing to participate in the research. Approval of the Ethics Committee has been obtained.

Briefly, a $6 \%$ suspension of fresh defibrinated human blood was prepared in sterile $1 \%$ glucose saline solution. The extracts were serially distributed into culture plates (96 wells) at concentrations ranging from 1000 to $1.5 \mu \mathrm{g} \mathrm{mL} \mathrm{m}^{-1}$. In sequence, $100 \mu \mathrm{L}$ of suspension of red blood cells was added. After $2 \mathrm{~h}$ of incubation at $37^{\circ} \mathrm{C}$, the culture plates were centrifuged at $3000 \mathrm{~g}$ for $5 \mathrm{~min}$ (Rotina 420, Hettich, Germany), and the hemolysis was measured in the supernatant using a microplate reader (Asys Hitech, Austria) at $550 \mathrm{~nm}$. A 4 \% solution of Triton X-100 (Sigma-Aldrich) was utilized as a positive control, whereas the suspension of non-treated cells was used as a negative control. The solvent used in the negative control was sterile $1 \%$ glucose saline solution. The results were expressed in the hemolysis percentage. The tests were performed in duplicate and replicated at least three times.

\section{Statistical analysis}

The results were first analyzed by the Shapiro-Wilk test to verify the normality distribution of the data. Given the assumption of normality, the data were subjected to analysis 
of variance by the F-test and the means were analyzed by the Scott-Knott test. Statistical differences were considered significant with $p$-value of less than 0.05 .

\section{RESULTS AND DISCUSSION}

\section{Chemical characterization}

In this study, nine extracts obtained from plants belonging to six different botanical families were selected, and their botanical name, traditional use and biological activity described in the literature are presented in Table I. We have performed a qualitative analysis of these plants parts by UHPLC-HRMS/MS, in positive and negative mode (Table II), as well as the antileishmanial activity against promastigote forms of L. amazonensis and $L$. braziliensis (Table III).

The chemical analysis of the aqueous extract of $H$. stigonocarpa fruits identified epicatechin and flavonoid glycoside, nicotiflorin, and epicatechin in the ethanolic extract. Fig. 1 shows a representative chromatogram (negative mode) of the ethanolic extract (Fig. 1a) and aqueous extract (Fig. 1b) of H. stigonocarpa fruits. Epicatechin was one of the main compounds present in the sap extracted by the perforation of the trunk and stem bark of $H$. stigonocarpa in a study by Farias et al. (18). Veggi et al. (19) and Sasaki et al. (20) found epicatechin in $H$. courbaril bark extract. A study of the phytochemical profile of methanolic extract of stem barks and fruit pulp of $H$. stigonocarpa indicated the presence of phenolic compounds, mainly flavonoids and condensed tannins (21).

The compounds piperlonguminine, chingchengenamide, piperine and piperolide were identified in the dichloromethane extract from the roots of P. corcovadensis (Figs. 2 $a, b)$. The piperlonguminine was also recognized by Costa and Mors (22) as a constituent of $P$. corcovadensis roots extract. Facundo et al. (23) isolated chingchengenamide. Piperine was isolated by Bezerra et al. (24) in P. tuberculatum root extract, whereas Mata et al. (25) identified piperolide in the extract of $P$. sanctum. Thus, the results found in the present work are in agreement with the ones previously reported in the literature regarding the composition of the dichloromethane extract from the roots of $P$. corcovadensis.

From the ethanolic extract of $A$. muricata leaves the chromatogram was obtained in the negative (Fig. 3a) and positive (Fig. $3 \mathrm{~b}$ ) ionization mode; it was possible to identify the presence of flavonoids (rutin, nicotiflorin and quercitrin), acetogenins (annomuricin A, annoreticuin-9-one and annonacin) and alkaloids (isoboldine and liriodenine). Rutin (26), nicotiflorin (27), quercitrin (28), annonacin and annomuricin (29), annoreticuin-9-one (30), liriodenine (31) and isoboldine (32) have already been isolated from A. muricata extract in the previous studies. Acetogenins were mainly obtained from leaves, roots and seeds and to a lower portion from the stem of A. muricata (33).

Phenolic compounds derived from cinnamic acid (caffeic acid, chlorogenic acid and ferulic acid), coumarin (scopoletin), an alkaloid (brunfelsamidine) and flavonoid (rutin) were identified in ethanolic extract of B. uniflora flowers (Fig. 4a,b), whereas scopoletin and brunfelsamidine were found in ethanolic extract of $B$. uniflora leaves (Fig. 5a,b). The presence of scopoletin isolated from the roots of $B$. uniflora ethanolic extract has been already reported (34), as well as caffeic and chlorogenic acid of the leaves (35). The alkaloid brunfelsamidine is present in the leaves, stems and roots of this same species (36). 


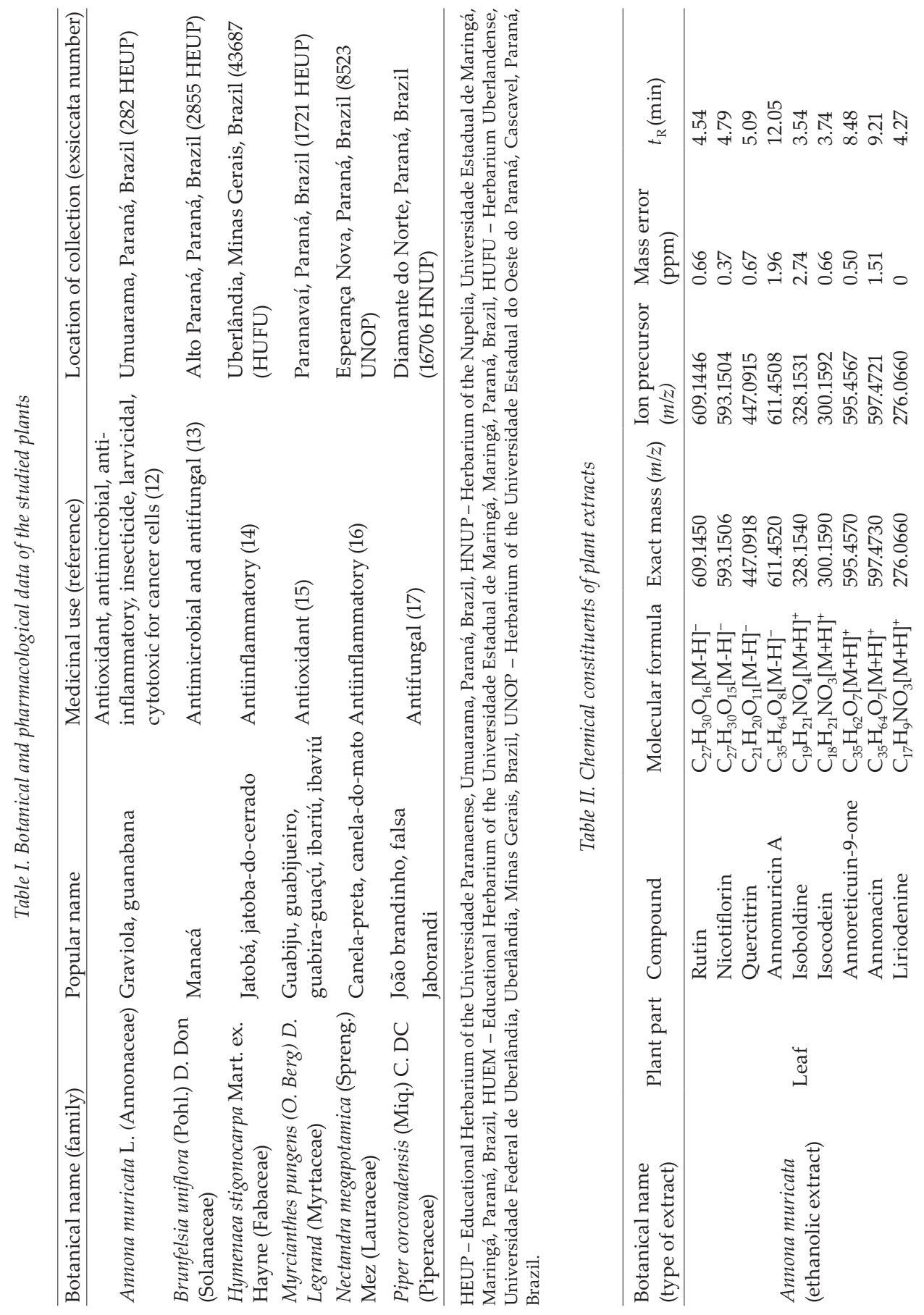




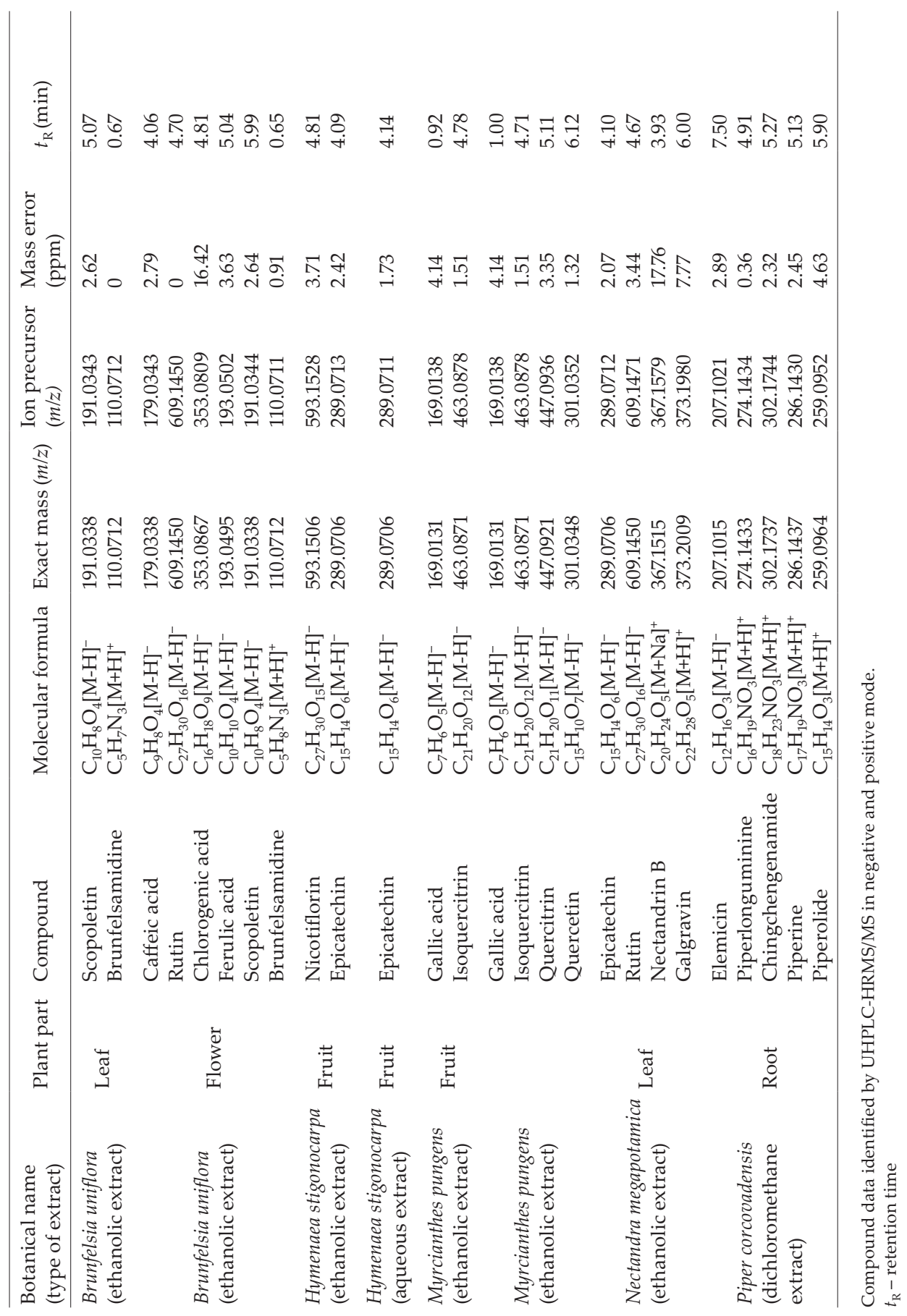




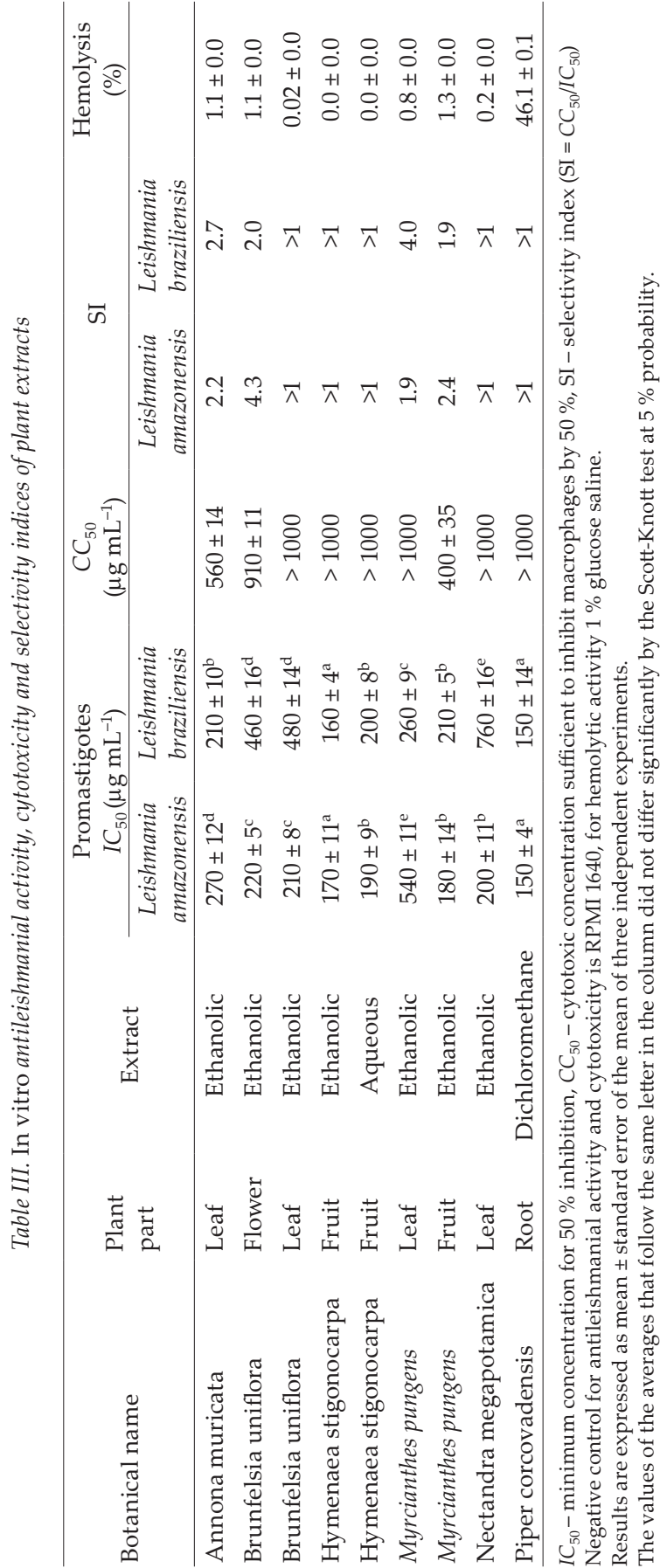

The results obtained by phytochemical analysis of $M$. pungens indicated the presence of gallic acid and isoquercitrin in the ethanolic extract of the fruits (Fig. 6a) and gallic acid, isoquercitrin, quercetin and quercitrin in the ethanolic extract of the leaves of $M$. pungens (Fig. 6b). De Almeida et al. (37) identified the flavonoids quercetin and quercitrin in the leaves extract of $M$. pungens. In the extract of the fruit, Andrade et al. (15) found quercitrin and isoquercitrin, whereas Seraglio et al. (38) detected gallic acid and isoquercetrin, corroborating well to our results. Quercetin and quercitrin have also been previously reported to have in vitro antileishmanial activity against $L$. amazonensis (39, 40).

Epicatechin, rutin, nectandrin B and galgravin were identified in the ethanolic extract of N. megapotamica leaves (Fig. 7a,b). The tetrahydrofuran lignan known as nectandrin B and galgravin were isolated from crude ethanolic extract of the leaves of $N$. megapotamica in a study by Silva-Filho et al. (41), corroborating with our results. Garcez et al. (16) identified epicatechin in the extract of $N$. megapotamica stem bark.

\section{Antileishmanial activity}

This study demonstrated that extracts from several plant species inhibited the growth of both L. amazonensis and L. braziliensis. The ethanolic extract of $H$. stigonocarpa fruits and di- 

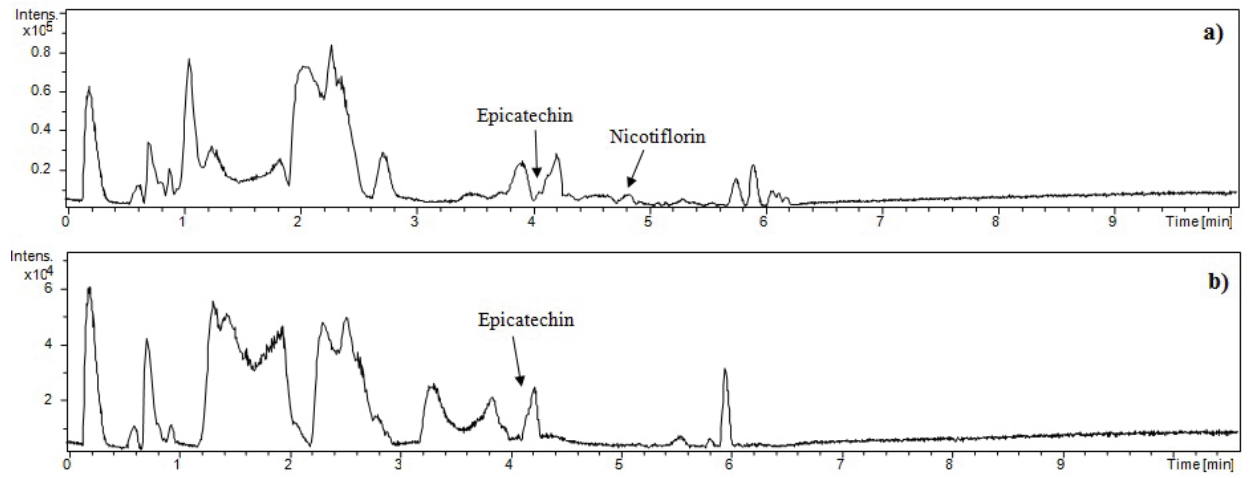

Fig. 1. Chromatographic profile of Hymenaea stigonocarpa fruit extracts obtained by UHPLC-HRMS/ MS in negative mode: a) ethanolic extract, b) aqueous extract.

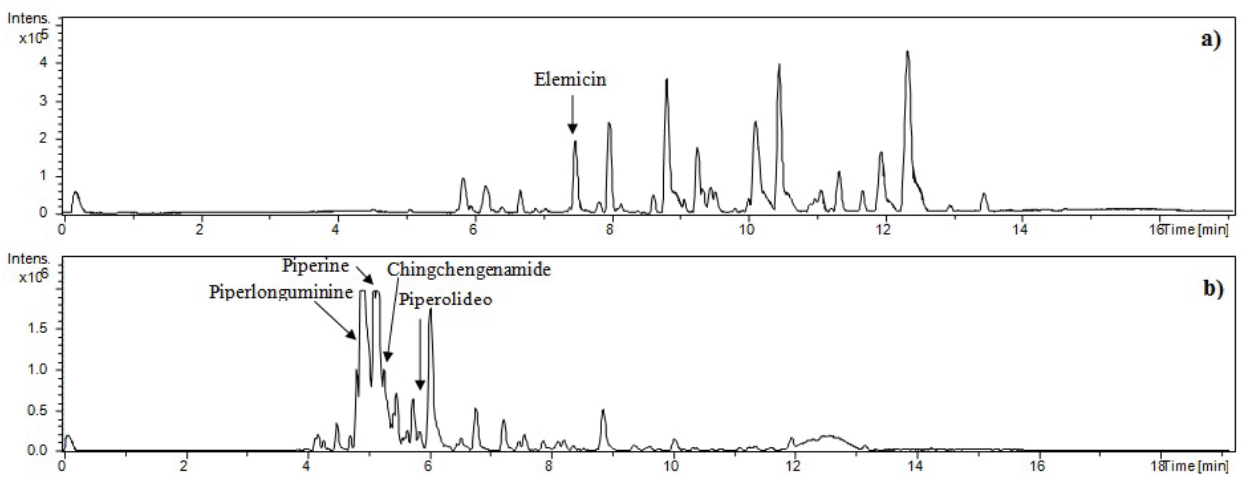

Fig. 2. Chromatographic profile of dichloromethane extract from the roots of Piper corcovadensis obtained by UHPLC-HRMS/MS: a) negative mode, b) positive mode.
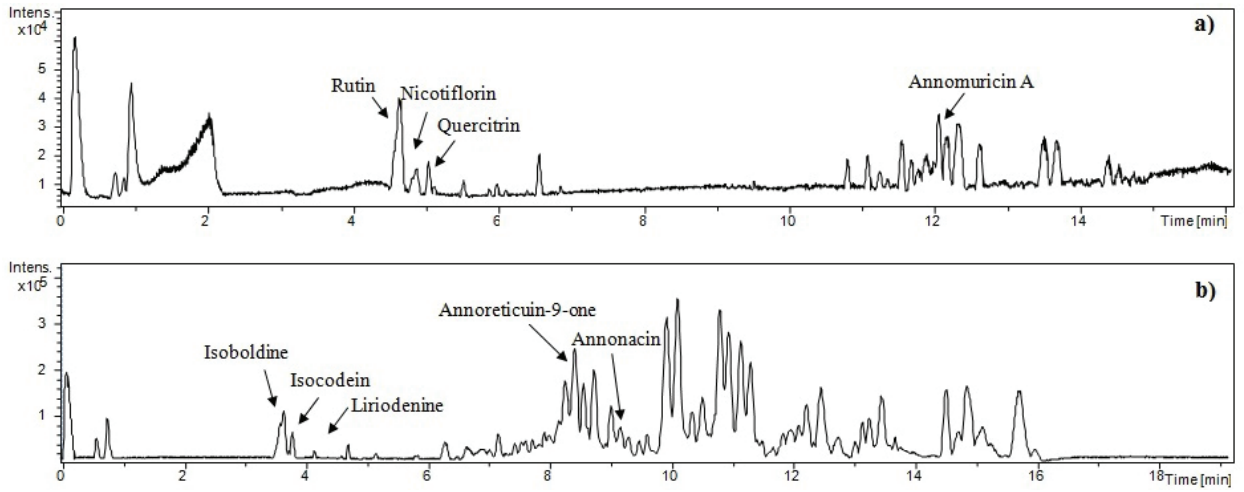

Fig. 3. Chromatographic profile of the ethanolic extract of the leaves of Annona muricata obtained by UHPLC-HRMS/MS: a) negative mode, b) positive mode. 


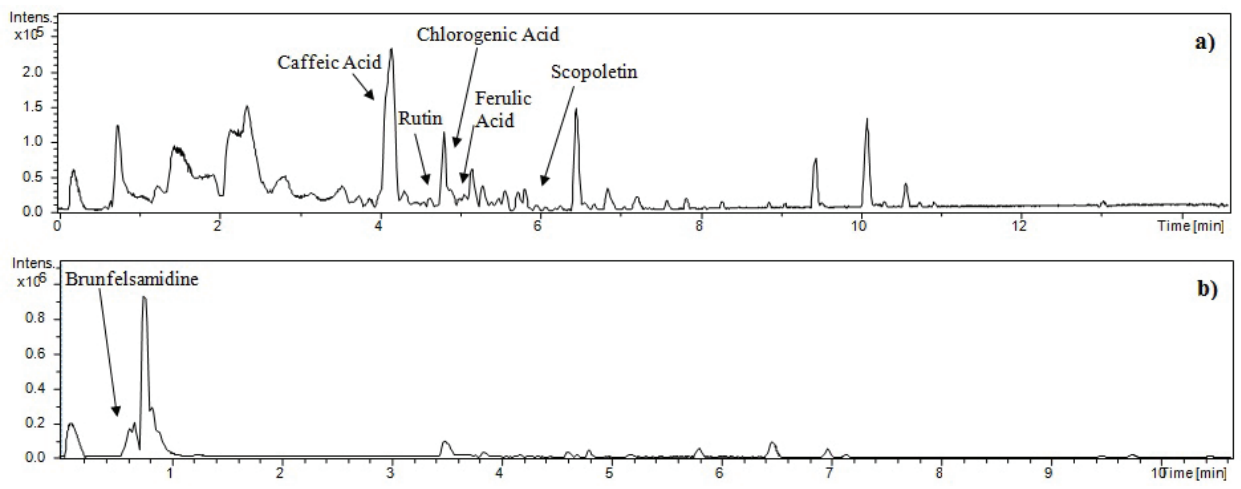

Fig. 4. Chromatographic profile of the ethanolic extract of the flower of Brunfelsia uniflora obtained by UHPLC-HRMS/MS: a) negative mode, b) positive mode.

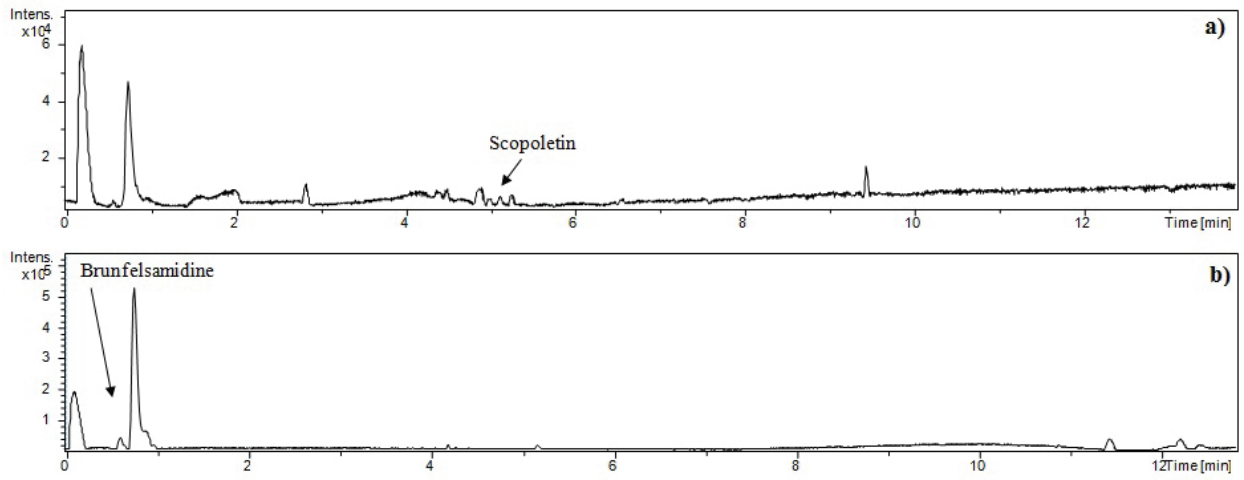

Fig. 5. Chromatographic profile of ethanolic extract of the leaves of Brunfelsia uniflora obtained by UHPLC-HRMS/MS: a) negative mode, b) positive mode.
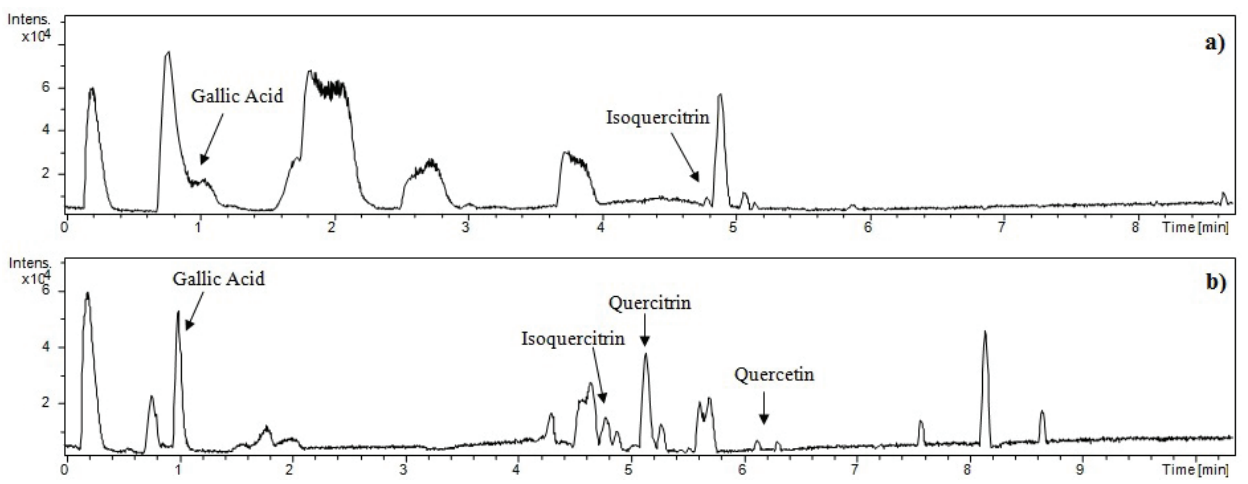

Fig. 6. Chromatographic profile of Myrcianthes pungens ethanolic extracts obtained by UHPLC-HRMS/ MS in negative mode: a) fruits, b) leaves. 


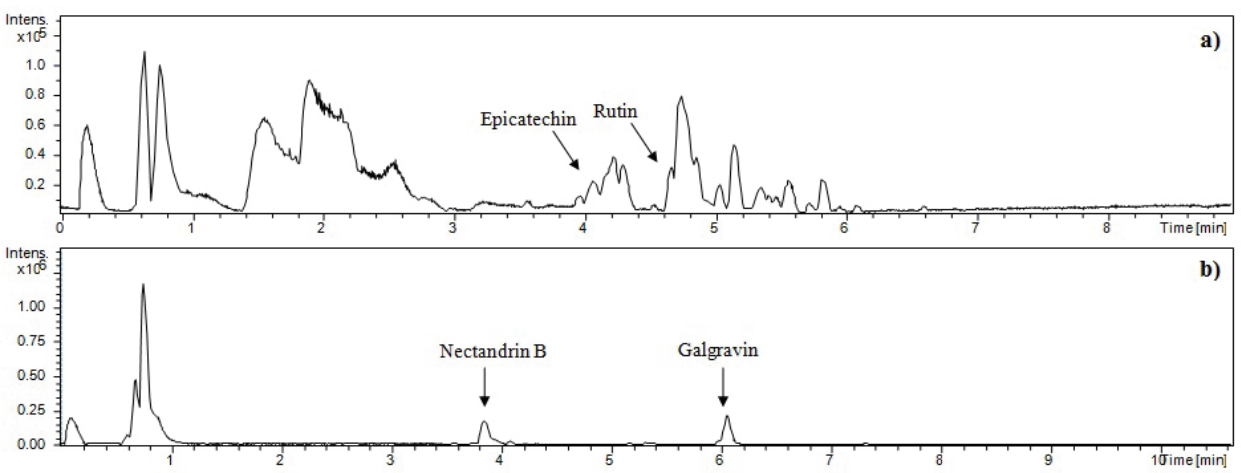

Fig. 7. Chromatographic profile of the ethanolic extract of Nectandra megapotamica leaves obtained by UHPLC-HRMS/MS: a) negative mode, b) positive mode.

chloromethane extract from the roots of $P$. corcovadensis were the most active against both protozoans, not differing statistically from each other (Table III).

The $I C_{50}$ values for $H$. stigonocarpa ethanolic extract were $170 \mu \mathrm{g} \mathrm{mL} \mathrm{L}^{-1}$ for L. amazonensis and $160 \mu \mathrm{g} \mathrm{mL}-1$ for L. braziliensis, whereas for the aqueous extract it was 190 and $200 \mu \mathrm{g} \mathrm{mL}^{-1}$, resp. Ribeiro et al. (42) found $I C_{50}$ of $199 \mu \mathrm{g} \mathrm{mL}^{-1}$ for hexane extract of $H$. stigonocarpa leaves against $L$. amazonensis, results similar to those found for $H$. stigonocarpa fruit extracts in our study.

Dichloromethane extract from the roots of $P$. corcovadensis presented $I C_{50}$ of 150 $\mu \mathrm{g} \mathrm{mL} \mathrm{m}^{-1}$ for both $L$. amazonensis and L. braziliensis. In studies with other Piper species, $I C_{50}$ results were similar to those found in this paper. Nakamura et al. (43), in a survey with extract of Piper regnellii leaves, found $I C_{50}$ of $167 \mu \mathrm{g} \mathrm{mL}^{-1}$ for hydroalcoholic extract, Sales $e t$ al. (44) found $I C_{50}$ of $143 \mu \mathrm{g} \mathrm{mL} \mathrm{m}^{-1}$ for the essential oil of Piper tuberculatum Jacq. fruit against L. braziliensis. Piperlongumine, an alkaloid amide isolated from $P$. tuberculatum, showed antileishmanial activity against $L$. infantum and L. amazonensis (45).

The ethanolic extract of A. muricata leaves, ethanolic extract of B. uniflora leaves and flowers, the aqueous extract of $H$. stigonocarpa fruits, ethanolic extract of $M$. pungens leaves and fruits, and ethanolic extract of $N$. megapotamica leaves showed $I C_{50}$ from 180 to $540 \mu \mathrm{g}$ $\mathrm{mL}^{-1}$ against L. amazonensis, whereas against L. braziliensis it varied from 200 to $760 \mu \mathrm{g} \mathrm{m}^{-1}$

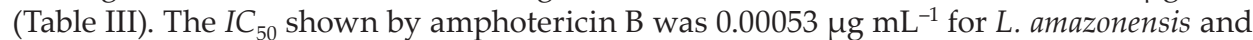
$0.0015 \mu \mathrm{g} \mathrm{mL} \mathrm{m}^{-1}$ for L. braziliensis.

Acetogenins in the ethanolic extract of $A$. muricata leaves were probably responsible for the observed antileishmanial activity (46). Although a clear structure-activity relationship has not yet been established for acetogenins, their leishmanicidal activity can be attributed to the number of hydroxy groups or the presence of a single tetrahydrofuran ring in their structure (47).

\section{Cytotoxicity in macrophages J774.A1}

To assess the potential application of the tested extracts in the treatment of leishmaniasis, the absence of toxicological effects against the host is required (48). Therefore, 
the possible cytotoxic effects of the extracts on J774.A1 macrophages and human red blood cells were evaluated. Our results indicated that the ethanolic and aqueous extracts of $H$. stigonocarpa fruits, dichloromethane extract from the roots of $P$. corcovadensis, ethanolic extract of N. megapotamica leaves and ethanolic extract of B. uniflora leaves showed low cytotoxicity for J774.A1 macrophages with $C_{50}>1000 \mu \mathrm{g} \mathrm{mL} \mathrm{m}^{-1}$ (Table III). The selectivity index (SI) was higher than 1 for all extracts evaluated, indicating a greater selectivity against the parasite in relation to mammal cells. These results are supported by Almeida et al. (49) and Tiuman et al. (50), who standardized the selectivity index over 1, suggesting that it indicates higher activity against protozoa and smaller activity against mammal cells.

\section{Hemolytic activity}

The extracts exerted low cytotoxicity in human red blood cells. The percentage of hemolysis ranged from 0 to $1.3 \%$ at the highest concentration tested $\left(1000 \mu \mathrm{g} \mathrm{mL}^{-1}\right)$, except for dichloromethane extract from the roots of P. corcovadensis which caused $46.1 \%$ hemolysis (Table III). In a study by Mello et al. (51) amphotericin B showed a strong hemolytic effect, causing 100 and $84.07 \%$ hemolysis at 0.13 and $0.01 \mathrm{mmol} \mathrm{L}^{-1}$, resp. Valdez et al. (11) also demonstrated a high percentage of hemolysis of amphotericin, $70 \%$ at $0.01 \mathrm{mmol} \mathrm{L}^{-1}$, concentration much lower than that used in our work.

\section{CONCLUSIONS}

In search of new substances with potential antileishmanial action, the extracts of $H$. stigonocarpa fruits and $P$. corcovadensis roots showed promising activity against L. amazonensis and L. braziliensis, and might be a potential source of active and less toxic compounds for the development of novel therapeutic agents to treat leishmaniasis. To the best of our knowledge, this is the first report on these species against two species of Leishmania. Additional experiments should be performed to isolate the active constituents of the most active plants, as well as to evaluate in vivo models for the treatment of these diseases.

Acknowledgements. - This study was financed in part by Fundação Araucária the Coordenação de Aperfeiçoamento de Pessoal de Nível Superior - Brazil (CAPES) Finance Code 001.

\section{REFERENCES}

1. A. A. S. Pereira, E. de Castro Ferreira, A. C. V. M. da Rocha Lima, G. B. Tonelli, F. D. Rêgo, A. P. Paglia, J. D. Andrade-Filho, G. F. Paz and C. M. F. Gontijo, Detection of Leishmania spp in silvatic mammals and isolation of Leishmania (Viannia) braziliensis from Rattus rattus in an endemic area for leishmaniasis in Minas Gerais State, Brazil, PLoS One 12 (2017) e0187704 (9 pages); https://doi. org/10.1371/journal.pone.0187704

2. I. Bennis, S. Thys, H. Filali, V. de Brouwere, H. Sahibi and M. Boelaert, Psychosocial impact of scars due to cutaneous leishmaniasis on high school students in Errachidia province, Morocco, Infect. Dis. Pov. 6 (2017) Article ID 46 (8 pages); https://doi.org/10.1186/s40249-017-0267-5

3. World Health Organization (WHO), Leishmaniasis, Copenhagen 2020; http://www.who.int/mediacentre/factsheets/fs375/en/; last access date June 16, 2020 
4. M. Khraiwesh, S. Leed, N. Roncal, J. Johnson, R. Sciotti, P. Smith, L. Read, R. Paris, T. Hudson, M. Hickman and M. Grogl, Antileishmanial activity of compounds derived from the medicines for malaria venture open access box against intracellular Leishmania major amastigotes, Am. J. Trop. Med. Hyg. 94 (2016) 340-347; https://doi.org/10.4269/ajtmh.15-0448

5. R. Delgado-Altamirano, L. Monzote, A. Piñón-Tápanes, H. Vibrans, J. F. Rivero-Cruz, C. IbarraAlvarado and A. Rojas-Molina, In vitro antileishmanial activity of Mexican medicinal plants, Heliyon 3 (2017) e00394 (19 pages); https://doi.org/10.1016/j.heliyon.2017.e00394

6. G. M. Cragg and D. J. Newman, Natural products: A continuing source of novel, Biochim. Biophys. Acta 1830 (2013) 3670-3695; https://doi.org/10.1016/j.bbagen.2013.02.008

7. B. B. Jensen, C. D. Comandolli-Wyrepkowski, A. M. C. Barros, F. V. Soares, I. Grafova, A. Grafov and A. M. R. Franco, Evaluation of activity anti-Leishmania in vitro of Tanacetum vulgare (Asteraceae), Acta Bras. 1 (2017) 33-37; https://doi.org/10.22571/Actabra12201716

8. A. G. Brenton and A. R. Godfrey, Accurate mass measurement: Terminology and treatment of data, J. Am. Soc. Mass Spectrom. 21 (2010) 1821-1835; https://doi.org/10.1016/j.jasms.2010.06.006

9. V. M. Marcussi, L. M. Marcussi, I. P. Barbosa-Tessmann, M. V. C. Lonardoni and T. G. V Silveira, Leishmania (Viannia) braziliensis: New primers for identification using polymerase chain reaction, Exp. Parasitol. 120 (2008) 300-305; https://doi.org/10.1016/j.exppara.2008.08.005

10. C. Williams, O. A. Espinosa, H. Montenegro, L. Cubilla, T. L. Capson, E. Ortega-Barrıa and L. I. Romero, Hydrosoluble formazan XTT: its application to natural products drug discovery for Leishmania, J. Microbiol. Methods 55 (2003) 813-816; https://doi.org/10.1016/J.MIMET.2003.08.013

11. R. H. Valdez, L. T. D. Tonin, T. Ueda-Nakamura, B. P. D. Filho, J. A. Morgado-Diaz, M. H. Sarragiotto and C. V. Nakamura, Biological activity of 1,2,3,4-tetrahydro- $\beta$-carboline-3-carboxamides against Trypanosoma cruzi, Acta Trop. 110 (2009) 7-14; https://doi.org/10.1016/J.ACTATROPICA.2008.11.008

12. Y. Gavamukulya, F. Wamunyokoli and H. A. El-Shemy, Annona muricata: Is the natural therapy to most disease conditions including cancer growing in our backyard? A systematic review of its research history and future prospects, Asian Pac. J. Trop. Med. 10 (2017) 835-848; https://doi. org/10.1016/j.apjtm.2017.08.009

13. L. C. T. Thiesen, E. Y. Y. Sugauara, V. Tešević, J. Glamočlija, M. Soković, J. E. Gonçalves, Z. C. Gazim, G. A. Linde and N. B. Colauto, Antimicrobial activity and chemical composition of Brunfelsia uniflora flower oleoresin extracted by supercritical carbon dioxide, Genet. Mol. Res. 16 (2017) Article ID 16029548 (12 pages); https://doi.org/10.4238/gmr16029548

14. P. R. Orsi, L. N. Seito, L. Claudio and D. Stasi, Hymenaea stigonocarpa Mart. ex Hayne: A tropical medicinal plant with intestinal anti-inflammatory activity in TNBS model of intestinal inflammation in rats, J. Ethnopharmacol. 151 (2014) 380-385; https://doi.org/10.1016/j.jep.2013.10.056

15. J. J. M. M. Andrade, A. L. Aboy, M. A. Apel, M. C. B. Raseira, J. F. M. Pereira and A. T. Henriques, Phenolic composition in different genotypes of guabiju fruits (Myrcianthes pungens) and their potential as antioxidant and antichemotactic agents, J. Food Sci. 76 (2011) 1181-1187; https://doi. org/10.1111/j.1750-3841.2011.02375.x

16. F. R. Garcez, W. S. Gacez, L. Hamerski and C. H. Miguita, Phenylpropanoids and other bioactive constituents from Nectandra megapotamica, Quim. Nova 32 (2009) 407-411; https://doi.org/10.1590/ S0100-40422009000200026

17. C. M. M. Fernandez-Andrade, K. Z. Bernuci, R. Y. Makimori and B. P. Dias, Atividade antifúngica do extrato hidroalcoólico de Piper corcovadensis (Miq.) C. DC., $6^{\circ}$ Congresso Ciências Farmacêuticas do Mercosul, $6^{0}$ Simpósio em Ciência e Tecnologia de Alimentos do Mercosul, Cascavel-ParanáBrazil, November 16-18, 2016.

18. K. de S. Farias, S. A. Auharek, A. L. Cunha-Laura, J. M. E. de Souza, G. A. Damasceno-Junior, M. C. Toffoli-Kadri, W. F. de O. Filiú, E. dos A. dos Santos, M. R. Chang and C. A. Carollo, Adulteration 
and contamination of commercial sap of Hymenaea species, Evid.-Based Complement. Altern. Med. 2017 (2017) Article ID 1919474 (13 pages); https://doi.org/10.1155/2017/1919474

19. P. C. Veggi, J. M. Prado, G. A. Bataglion, M. N. Eberlin and M. A. A. Meireles, Obtaining phenolic compounds from jatoba (Hymenaea courbaril L.) bark by supercritical fluid extraction, J. Supercrit. Fluids 89 (2014) 68-77; https://doi.org/10.1016/j.supflu.2014.02.016

20. K. Sasaki, Y. Matsukura, K. Shijima, M. Miyake, D. Fujiwara and Y. Konishi, High-performance liquid chromatographic purification of oligomeric procyanidins, trimers up to nonamers, derived from the bark of jatoba (Hymenaea courbaril), Biosci. Biotechnol. Biochem. 73 (2014) 1274-1279; https:// doi.org/10.1271/bbb.80747

21. P. R. Orsi, F. Bonamin, J. A. Severi, R. C. Santos, W. Vilegas, C. A. Hiruma-Lima and L. C. Di Stasi, Hymenaea stigonocarpa Mart. ex Hayne: A Brazilian medicinal plant with gastric and duodenal antiulcer and antidiarrheal effects in experimental rodent models, J. Ethnopharmacol. 143 (2012) 81-90; https://doi.org/10.1016/j.jep.2012.06.001

22. S. S. Costa and W. B. Mors, Amides of Ottonia corcovadensis, Phytochemistry 20 (1981) 1305-1307; https://doi.org/10.1016/0031-9422(81)80027-1

23. V. A. Facundo, S. M. Morais and R. B. Filho, Chemical constituents of Ottonia corcovadensis Miq. from Amazon forest $-{ }^{1} \mathrm{H}$ and ${ }^{13} \mathrm{C}$ chemical shift assignments, Quim Nova 27 (2004) 79-83; https://doi. org/10.1590/S0100-40422004000100017

24. D. P. Bezerra, F. O. Castro, A. P. N. N. Alves, C. Pessoa, M. O. Moraes, E. R. Silveira, M. A. S. Lima, F. J. M. Elmiro and L. V. Costa-Lotufo, In vivo growth-inhibition of sarcoma 180 by piplartine and piperine, two alkaloid amides from Piper, Braz. J. Med. Biol. Res. 39 (2006) 801-807; https://doi. org/10.1590/S0100-879X2006000600014

25. R. Mata, I. Morales, O. Pérez, I. Rivero-Cruz, L. Acevedo, I. Enriquez-Mendoza, R. Bye, S. Franzblau and B. Timmermann, Antimycobacterial compounds from Piper sanctum, J. Nat. Prod. 67 (2004) 1961-1968; https://doi.org/10.1021/np0401260

26. A. Matsushige, Y. Kotake, K. Matsunami, H. Otsuka, S. Ohta and Y. Takeda, Three new megastigmanes from the leaves of Annona muricata, J. Nat. Med. 66 (2012) 284-291; https://doi.org/10.1007/ s11418-011-0583-1

27. S. H. Park, H. S. Shin, N. H. Lee, I. K. Hong and S. N. Park, Cellular protective effects and mechanisms of kaempferol and nicotiflorin isolated from Annona muricata against ${ }^{1} \mathrm{O}_{2}$-induced Damage, Appl. Chem. Eng. 29 (2018) 49-55; https://doi.org/10.14478/ace.2017.1097

28. P. Dos S. da Rocha, J. F. Campos, V. Nunes-Souza, M. do C. Vieira, A. P. de A. Boleti, L. A. Rabelo, E. L. Dos Santos and K. de P. Souza, Antioxidant and protective effects of Schinus terebinthifolius Raddi against doxorubicin-induced toxicity, Appl. Biochem. Biotechnol. 184 (2018) 869-884; https:// doi.org/10.1007/s12010-017-2589-y

29. M. C. Jaramillo, G. J. Arango, M. C. Gonzalez, S. M. Robledo and I. D. Velez, Cytotoxicity and antileishmanial activity of Annona muricata pericarp, Fitoterapia 71 (2000) 183-186; https://doi.org/10.1016/ s0367-326x(99)00138-0

30. C. Y. Ragasa, G. Soriano, O. B. Torres, D. Ming-Jaw and S. Chien-Chang, Acetogenins from Annona muricata, Pharmacogn. J. 4 (2012) 32-37; https://doi.org/10.5530/pj.2012.32.7

31. S. Fofana, A. Keita, S. Balde, R. Ziyaev and S. F. Aripova, Alkaloids from leaves of Annona muricata Chem. Nat. Compd. 48 (2012) 714; https://doi.org/10.1007/s10600-012-0363-5

32. A. V Coria-Téllez, E. N. Obledo-Vázquez, E. Padilla-Camberos, M. González-Ávila and M. Martínez-Velázquez, Bioactivity, nutritional property, and rapid chemical characterization of aqueous extract of Annona muricata leaf from Mexico, Trop. J. Pharm. Res. 18 (2019) 611-617; https://doi. org/10.4314/tjpr.v18i3.24

33. F.-R. Chang, C.-C. Liaw, C.-Y. Lin, C.-J. Chou, H.-F. Chiu and Y.-C. Wu, New adjacent bis-tetrahydrofuran annonaceous acetogenins from Annona muricata, Planta Med. 69 (2003) 241-246; https://doi. org/10.1055/s-2003-38485 
34. E. J. Oliveira, M. A. Romero, M. S. Silva, B. A. Silva and I. A. Medeiros, Intracellular calcium mobilization as a target for the spasmolytic action of scopoletin, Planta Med. 67 (2001) 605-608; https:// doi.org/10.1055/s-2001-17355

35. M. B. G. Martins, R. de R. Graf, A. J. Cavalheiro and S. D. Rodrigues, Caracterização anatômica, química e antibacteriana de folhas de Brunfelsia uniflora (manacá) presentes na Mata Atlântica, Braz. J. Pharmacogn. 19 (2009) 106-114; https://doi.org/10.1590/S0102-695X2009000100020

36. C. Birkner, G. Stapel, S. Leyck, H. Fischer, B. Christ and K. Kesselring, Extraction of hopamidine, Ger. Pat. 3,506,643, 1986.

37. A. L. de Almeida, M. L. Beleza, A. Campos, R. L. da Rosa, S. F. de Andrade, V. C. Filho and L. A. N. Nesello, Phytochemical profile and gastroprotective potential of Myrcianthes pungens fruits and leaves, Nutrire 42 (2017) Article ID 24 (5 pages); https://doi.org/10.1186/s41110-017-0040-3

38. S. K. T. Seraglio, M. Schulz, P. Nehring, F. D. Betta, A. C. Valese, H. Daguer, L. V. Gonzaga, R. Fett and A. C. O. Costa, Nutritional and bioactive potential of Myrtaceae fruits during ripening, Food Chem. 239 (2018) 649-656; https://doi.org/10.1016/j.foodchem.2017.06.118

39. M. F. Muzitano, L. W. Tinoco, C. Guette, C. R. Kaiser, B. Rossi-Bergmann and S. S. Costa, The antileishmanial activity assessment of unusual flavonoids from Kalanchoe pinnata, Phytochemistry 67 (2006) 2071-2077; https://doi.org/10.1016/j.phytochem.2006.06.027

40. M. F. Muzitano, C. A. B. Falcão, E. A. Cruz, M. C. Bergonzi, A. R. Billa, F. F. Vincieri, B. R. RossiBergmann and S. S. Costa, Oral metabolism and efficacy of Kalanchoe pinnata flavonoids in a murine model of cutaneous leishmaniasis, PlantaMed.75(2009)307-311;https://doi.org/10.1055/s-0028-1088382

41. A. A. da S. Filho, S. Albuquerque, M. L. A. e Silva, M. N. Eberlin, D. M. Tomazela and J. K. Bastos, Tetrahydrofuran lignans from Nectandra megapotamica with trypanocidal activity, J. Nat. Prod. 67 (2004) 42-45; https://doi.org/10.1021/np0302697

42. T. G. Ribeiro, M. A. Chávez-Fumagalli, D. G. Valadares, J. R. Franca, P. S. Lage, M. C. Duarte, P. H. R. Andrade, V. T. Martins, L. E. Costa, A. L. A. Arruda, A. A. G. Faraco, E. A. F. Coelho and R. O. Castilho, Antileishmanial activity and cytotoxicity of Brazilian plants, Exp. Parasitol. 143 (2014) 60-68; https://doi.org/10.1016/j.exppara.2014.05.004

43. C. V. Nakamura, A. O. Santos, M. C. Vendrametto, P. S. Luize B. P. D. Filho, D. A. G. Cortez and T. Ueda-Nakamura, Antileishmanial activity of hydroalcoholic extract and fractions obtained from leaves of Piper regnellii (Miq.) C. DC. var. pallescens (C. DC.), Rev. Bras. Farmacogn. 16 (2006) 61-66; https://doi.org/10.1590/S0102-695X2006000100011

44. V. dos S. Sales, Á. B. Monteiro, G. de A. Delmondes, E. P. do Nasimento, F. R. S. D. N. de Figuêiredo, C. K. de S. Rodrigues, J. F. E. de Lacerda, C. N. Fernandes, M. de O. Barbosa, A. X. Brasil, S. R. Tintino, M. C. V. Gomez, C. Coronel, H. D. M. Coutinho, J. G. M. da Costa, C. F. B. Felipe, I. R. A. de Menezes and M. R. Kerntopf, Antiparasitic activity and essential oil chemical analysis of the Piper tuberculatum Jacq fruit, Iran. J. Pharm. Res. 17 (2018) 268-275.

45. F. de L. Moreira, T. B. Riul, M. de L. Moreira, A. C. Pilon, M. Dias-Baruffi, M. S. S. Araújo, N. P. Lopes and A. R. M. de Oliveira, Leishmanicidal effects of piperlongumine (Piplartine) and its putative metabolites, Planta Med. 84 (2018) 1141-1148; https://doi.org/10.1055/a-0614-2680

46. E. Osorio, G. J. Arango, N. Jiménez, F. Alzate, G. Ruiz, D. Gutiérrez, M. A. Paco, A. Giménez and S. Robledo, Antiprotozoal and cytotoxic activities in vitro of Colombian Annonaceae, J. Ethnopharmacol. 111 (2007) 630-635; https://doi.org/10.1016/j.jep.2007.01.015

47. M. J. Chan-Bacab and L. M. Peña-Rodríguez, Plant natural products with leishmanicidal activity, Nat. Prod. Rep. 18 (2001) 674-688; https://doi.org/10.1039/B100455G

48. C. E. S. Carvalho, E. P. C. Sobrinho-Junior, L. M. Brito, L. A. D. Nicolau, T. P. Carvalho, A. K. S. Moura, K. A. F. Rodrigues, S. M. P. Carneiro, D. D. R. Arcanjo, A. M. G. L. Citó and F. A. A. Carvalho, Anti-Leishmania activity of essential oil of Myracrodruon urundeuva (Engl.) Fr. All.: Composition, cytotoxity and possible mechanisms of action, Exp. Parasitol. 175 (2017) 59-67; https://doi. org/10.1016/j.exppara.2017.02.012 
49. T. L. de Almeida, J. A. Monteiro, G. K. P. Lopes, L. U. R. Chiavelli, S. M. de O. Santin, C. C. da Silva, V. Kaplum, D. B. Scariot, C. V. Nakamura, A. L. T. G. Ruiz, J. E. de Carvalho, R. T. de Faria and A. M. Pomini, Estudo químico e atividades antiproliferativa, tripanocida e leishmanicida de Maxillaria picta, Quim Nov. 37 (2014) 1151-1157; https://doi.org/10.5935/0100-4042.20140179

50. T. S. Tiuman, T. Ueda-Nakamura, D. A. G. G. Cortez, B. P. D. Filho, J. A. Morgado-Díaz, W. de S. Souza and C. V. Nakamura, Antileishmanial activity of parthenolide, a sesquiterpene lactone isolated from Tanacetum parthenium, Antimicrob. Agents Chemother. 49 (2005) 176-182; https://doi. org/10.1128/AAC.49.11.176

51. T. F. P. de Mello, H. R. Bitencourt, R. B. Pedroso, S. M. A. Aristides, M. V. C. Lonardoni and T. G. V Silveira, Leishmanicidal activity of synthetic chalcones in Leishmania (Viannia) braziliensis, Exp. Parasitol. 136 (2014) 27-34; https://doi.org/10.1016/j.exppara.2013.11.003 